\title{
7 \\ The IMF and Fossil Fuel Subsidies
}

\author{
The Unexpected Environmentalist
}

The IMF is one of the most powerful institutions in the world, often criticised for forcing governments to adopt fundamental policy changes that reflect the worldview of IMF officials rather than the preferences of the government or the electorate (Barnett and Finnemore, 2004). The criticism has particularly focused on the IMF's insistence on promoting policies rooted in the so-called Washington Consensus including trade, financial and labour market liberalisation and cutting fiscal deficits (Babb, 2013; Chwieroth, 2008). Environmental protection has rarely been included among the IMF's top priorities, and the IMF has been criticised for the environmental consequences of its policies (Harvey, 2005; Shandra et al., 2011). Against this backdrop, the IMF's involvement with fossil fuel subsidies is striking: not only did it seem to emerge out of the blue in 2013, but it also placed the IMF among the most radical of the institutions addressing climate change. This chapter proceeds with an outline of this seemingly radical change as well as the IMF's use of conditionalities to promote fossil fuel subsidy reform, followed by a discussion of how this output was driven by IMF officials and shaped by the economic worldview of the IMF. Finally, the chapter finds that the output had some cognitive impact at the international level but had more important ramifications at the domestic level.

\subsection{Output: Conditionalities and Carbon Pricing}

IMF output has addressed fossil fuel subsidies along two strands, both increasing in importance. First, a strand consisting of bilateral interactions with countries experiencing fiscal problems exacerbated by fossil fuel subsidies and including policy recommendations and IMF programmes inter alia promoting subsidy reform to improve fiscal balances (interview with IMF senior official, 17 February 2015). This strand is composed mainly of distributive output in the shape of conditionalities, particularly that the country in question would receive IMF loans only if it 
embarked on reforms including subsidy reform. Yet, to a lesser degree, the strand also consists of knowledge output in the shape of analyses of the consequences of such reforms and the best ways to undertake them. For decades, the IMF has been opposed to subsidies, especially consumer subsidies fixing the prices of goods, because of their fiscal and macroeconomic impact. The former has been problematic in the eyes of the IMF because subsidies constitute sizeable budget items including at times of fiscal deficits, the latter because subsidies distort the allocation in markets by fixing or supporting prices. At times, subsidies (for fossil fuels as well as other products such as food) have been phased out or cut significantly as a result of IMF insistence, for example, in Egypt (Sherry et al., 2014) and Sudan (Michael, 2013). Over the past ten years, fossil fuel subsidies have been singled out in an increasing number of IMF recommendations to individual countries and have increasingly been treated as distinct from other kinds of subsidies. The IMF has suggested phasing out such subsidies because they are an inefficient, fiscally costly and often economically distorting way of providing welfare benefits (interview with IMF officials, 9 April 2014). The ongoing IMF Extended Credit Facility Arrangement (a kind of IMF programme) for Burkina Faso constitutes an example of this, with detailed recommendations on how Burkina Faso should liberalise the government-fixed fuel prices (IMF, 2015a; interview with senior IMF official, 22 June 2016). This strand mainly emphasises the fiscal consequences of the fossil fuel subsidies, while also stressing the distributional (both positive and negative) and macroeconomic consequences. Environmental consequences (including local externalities) have been accentuated to a lesser extent. In the case of Burkina Faso, the IMF policy was developed by local IMF officials and officials from the Fiscal Affairs Department, and focused on what the IMF refers to as pre-tax subsidies, namely the subsidies lowering consumer prices below the international market price plus distribution costs, not the absence of a full pricing of the externalities (interview with senior IMF official, 22 June 2016). Not including an incomplete pricing of externalities distinguishes the IMF's approach to fossil fuel subsidies in Burkina Faso from its approach to fossil fuel subsidies globally, which did include such non-pricing (see subsequent discussion of the IMF's fossil fuel subsidy definition).

The second strand consists of knowledge output and focuses on the lack of a carbon price (and environmental taxes generally) and on solving this problem from the perspective of an economist, that is, getting the price right (interview with IMF senior official, 17 February 2015). Prior to 2008, the IMF only occasionally addressed subsidies including energy (rather than fossil fuel) subsidies in policy reports $^{1}$ (Baig et al., 2007; Gupta et al., 2000) and in country-specific policy

\footnotetext{
${ }^{1}$ Which were not part of IMF programmes but more analytical.
} 
recommendations (see e.g. IMF 2004). Energy subsidies were framed in terms of fiscal and macroeconomic impact, without referring to the environmental impact. Thus, subsidising fossil fuels was framed as being similar to subsidising any other product. The IMF used price-gap approaches to measure all kinds of subsidies, and did not include externalities in its fuel benchmark prices (e.g. Said and Leigh, 2006), which meant that getting the price right at this stage did not signify including the costs of externalities in the price.

In 2008 the first official publications ${ }^{2}$ to address fuel subsidies as a distinct concept and to include environmental externalities (priced at USD 0.50 per litre petrol and diesel) were published (IMF, 2008a, 2008b). They would provide the blueprint for future IMF output in fossil fuel subsidies. After 2008 the IMF increasingly addressed fossil fuel subsidies and their environmental impact, while maintaining the emphasis on fiscal and macroeconomic consequences. In 2013, they published the report 'Energy subsidy reform: lessons and implications' (Clements et al., 2013) which raised the IMF's engagement with fossil fuel subsidies to a new level. Crucially, the report used a price-gap approach based on a benchmark price including both value-added tax (VAT) and the social cost of externalities, particularly climate change and other environmental externalities such as local air pollution. This approach was adopted on the basis of the IMF's work on fiscal instruments (in the Fiscal Affairs Department) and the emphasis on as the title of a key publication on fossil fuel subsidies says - Getting Energy Prices Right (Parry et al., 2014). The IMF has also offered an online course on Energy Subsidy Reform based on these publications. The notion of 'getting prices right' constitutes a framing of fossil fuel subsidies as being problematic in normative terms because they cause prices to be 'wrong' in the sense of preventing the optimal allocation in markets. A price is right if it reflects all production-related costs to society as well as all benefits to the buyer, as determined in a market where the only government intervention consists of taxes addressing negative externalities, or subsidies addressing positive externalities. Importantly, the notion of including non-priced externalities in the definition of a subsidy was hardly discussed outside the IMF prior to 2013 (one exception being Hodas, 2006).

The cognitive and normative dimensions of this notion are closely intertwined: fossil fuel subsidies are defined (cognitively) in terms of getting the prices wrong, and they are normatively problematic because they get the prices wrong. One can compare this framing of the right price to the proponents of fossil fuel consumption subsidies, who argue that the price is right if it is low enough to allow everybody to buy it, and - in the case of fossil fuel producing countries - allows for people to get

\footnotetext{
2 IMF working papers from 2006 and 2007 by IMF staff had addressed fuel subsidies, but as working papers they did not require official IMF endorsement.
} 
'their share' of the fossil fuel resources of that country (Cheon et al., 2013). Regarding distributive consequences, the IMF framed fossil fuel subsidies as a highly ineffective way of supporting low-income households, since most of the subsidies are captured by citizens with above-average incomes (Arze del Granado and Gillingham, 2012).

The framing also closely linked fossil fuel subsidies to another policy issue, namely carbon pricing. The IMF reports explicitly referred to Pigouvian or corrective taxes as the optimal way of correcting externalities, drawing on the works of the economist Arthur Pigou. Pigou (1932) invented the concept of an externality defined as the cost or benefit of an activity undertaken by one actor that affects another actor not involved in the activity, thus creating a suboptimal situation since the costs of the activity do not reflect the true costs or benefits to society (see also Chapter 1). Furthermore, Pigou developed the notion that externalities should be corrected by placing taxes (or financial support) on the activity creating the externality that corresponds to the social costs (or benefits). For instance, burning coal incurs costs to other parts of society that are not borne by the polluter, and consequently should be corrected by a Pigouvian tax on coal burning corresponding to the environmental damage. Or a positive externality such as non-patented research should receive support corresponding to the social benefit. The linking of fossil fuel subsidies and carbon pricing is closely related to the IMF increasingly advocating carbon pricing, particularly carbon taxes, as the most important climate mitigation instrument (IMF, 2019c, 2019e; Lagarde, 2015; Mooij et al., 2012; Parry, 2019; Parry et al., 2018).

Importantly, the IMF explicitly endorsed environmental taxes over other environmental policy instruments, including not only regulatory standards such as emission standards, which were never popular among neoclassical economists (Lauber and Schenner, 2011; Meckling and Allan, 2020), but also over emission trading schemes, an alternative carbon pricing instrument. Neoclassical environmental economists have been divided over whether environmental taxes or emissions trading schemes constitute the most optimal instrument. Whereas advocates of taxes draw on Pigou's arguments for letting the polluter bear the social costs of pollution, advocates of trading schemes draw on economist Ronald Coase (1960), who argued that the right to pollute should be divided between actors, who could then trade these rights and thus create a price on emissions through trading. According to Coase, the social costs of pollution should not necessarily be borne by the polluter. Other actors working with fossil fuel subsidies had not linked it to carbon pricing, and in carbon pricing circles, fossil fuel subsidies had been mentioned only as a detriment to effective carbon pricing without framing the absence of carbon pricing as a subsidy (see OECD, 2009). It is worth comparing the IMF's 
endorsement of Pigouvian taxes to that of the World Bank, which has been very active in promoting carbon pricing, but initially promoted emissions trading and only at a later stage promoted carbon taxes on a par with emissions trading (Skovgaard and Canavan, 2020).

The findings of the report were extended and updated in a 2015 IMF working paper (Coady et al., 2015), whose estimate of global subsidies at USD 5300 billion $^{3}$ in 2015 - compared to estimates of USD 1900 billion in the 2013 report USD (Clements et al., 2013) and USD 550 billion in the IEA's 2014 World Energy Outlook (IEA, 2014) - received significant attention. This increase was due to a revision upwards of the assessments of externalities - especially air pollution. In 2019, the IMF updated its 2015 analysis with new data and found that very little had changed: global fossil fuel subsidies were estimated at USD 5,200 billion for 2017 (Coady et al., 2019).

According to both the 2015 and 2019 analyses, local air pollution accounted for little less than half of the subsidies, climate change for little less than one quarter, with reductions to consumption taxes, direct subsidies and non-air local externalities (congestion, traffic accidents, etc.) for the remaining part (Coady et al., 2015, 2019). Regarding climate change, the social cost of emitting a ton of $\mathrm{CO}_{2}$ was in 2015 estimated at USD 35 (based on Parry et al., 2014) and USD 40 in 2019 (Coady et al., 2019), figures originating from the US government's Interagency Working Group on Social Cost of Carbon (respectively Interagency Working Group on Social Cost of Carbon, 2013, 2016). The USD 35 and 40 per ton social costs are low estimates, based on William D. Nordhaus' DICE model, which has been criticised for seriously under-estimating the costs of climate change (Howard and Sterner, 2017). In comparison, Richard Tol's (2011) meta study of different estimates of the social cost of carbon arrives at a mean of USD 177 per ton (although most of the estimates are below this mean), and the High-Level Commission on Carbon Pricing (2017) estimated that carbon prices should be between USD 40 and 80 per ton by 2020 to meet the Paris Agreement's target of temperature increases 'well below 2 degrees' (UNFCCC, 2015). Interestingly, one of the IMF's reports from 2019 advocating carbon taxes operated with a carbon price of USD 75 per ton being required to meet the 2-degree target (IMF, 2019e). ${ }^{4}$ Yet, the USD 35 and USD 40 estimates are high compared to actual levels of carbon taxation. Only about 20 per cent of global emissions are currently covered by such taxes, with about half of these emissions priced at below USD 10 per ton, and only 5 per cent of them above USD 40 per ton (World Bank, 2020b).

\footnotetext{
3 Also including the OECD's estimate of producer subsidies for 2011 being worth USD 16.8 billion.

${ }^{4}$ Defining a carbon price of USD 75 per ton as necessary for meeting the 2-degree target does not necessarily contradict the notion of a USD 40 per ton price as the economically optimal solution. The IMF may estimate that it is optimal to allow temperature increases of more than 2 degrees, and hence a price of USD 40 is optimal.
} 
According to the IMF's definition, practically all states subsidise fossil fuels, even countries with carbon taxes that do not fully price externalities. Developed countries account for a quarter of energy subsidies, and emerging and developing Asia for half (Coady et al., 2015). Consequently, the 2013 and 2015 reports break with previous analyses which - using different definitions - identified fossil fuel subsidies as a phenomenon primarily seen in developing countries. The reports also contradicted the claims of influential IMF member states (including the United Kingdom and Japan) that they do not subsidise fossil fuels these (Kirton et al., 2013), something which made the report unpopular among the governments of those countries but popular among NGOs. In 2020, the IMF planned to integrate climate mitigation issues, including carbon pricing, in its bilateral Article IV consultations (which are carried out with all member states), although these consultations were temporarily postponed because of the coronavirus pandemic (interview with senior IMF official, 19 May 2020).

\subsection{Causes}

The most important factor influencing the decision to address fossil fuel subsidies (the first aspect of economisation) was policy entrepreneurs within the IMF, who together with the institutional worldview shaped how the IMF addressed the issue. From 2005 onwards, fossil fuel subsidies gained increasing attention, particularly driven by the fiscal impact of high oil prices (2005-8 and 2011-14) and the 'Poverty and Social Impact Analysis Group' within the Fiscal Affairs Department. More specifically, IMF officials, including members of this analysis group, provided technical assistance to countries suffering from the costs of subsidising expensive fossil fuels and wanting to reform these subsidies, and this experience increased the awareness of the subsidies and how to address them (interview with IMF official, 25 February 2015). Consequently, the IMF stressed the fiscal impact of fossil fuel subsidies while stressing the importance of mitigating measures to protect the poor (interview with IMF official, 25 February 2015). Thus, the contextual factor of high oil prices provided policy entrepreneurs within the IMF with a window of opportunity. As mentioned in Section 7.1, from 2008 onwards, the IMF has increasingly singled out fossil fuel subsidies from other subsidies and stressed their environmental impact; a development in framing that was due to policy entrepreneurship within the organisation.

The notion of including environmental externalities in measures of efficient fuel prices had been floating around for some time among a circle of economists working for the IMF, the World Bank, the US government and various environmental think tanks in Washington DC (interview with senior IMF economist, 
24 April 2014). The IMF economists within this group also promoted the notion of including undercharging for environmental costs in a broad definition of fossil fuel subsidies, and such undercharging has received considerable attention from IMF management since 2011 under Christine Lagarde (interview with senior IMF economist, 24 April 2014). Lagarde took a more active interest in climate politics than her predecessors, which opened a window of opportunity for the aforementioned economists. With few exceptions, all publications addressing fossil fuel subsidies since the 1990s have been authored by at least one of the key IMF economists working on fossil fuel subsidies: David Coady, Ian Parry and Benedict Clements. Of these, Parry has a background in environmental energy taxation (with a $\mathrm{PhD}$ from the University of Chicago), and has argued the case for carbon taxes in academic and IMF publications (Parry, 2015, 2019; Parry et al., 2014, 2018) as well as being the Fund's leading expert on such taxes and environmental fiscal policy in general. He arrived at the IMF in 2010, when the Fund's interest in the under-pricing of externalities from fossil fuel use was increasing. David Coady is the Chief of the Expenditure Policy Division of the Fiscal Affairs Department and has mainly worked and published on the distributional effects of public policies (and earned his $\mathrm{PhD}$ from the London School of Economics). Similarly, Benedict Clements (at the time of writing Chief of the Fiscal Policy and Surveillance Division of the Fiscal Affairs Department, holding a PhD from the University of Notre Dame) has worked and published on public and fiscal policy. Both Coady and Clements have been working on subsidies at the IMF since the Fund first started addressing the issue (Baig et al., 2007; Clements et al., 1998).

In terms of the second aspect of economisation, how fossil fuel subsidies were addressed, the policy entrepreneurs particularly from the Fiscal Affairs Department were important in framing the environmental impact in neoclassical terms (as discussed in Section 7.1). There is nothing surprising about the Fiscal Affairs Department adopting a neoclassical approach, since it - even more than other IMF Departments - has been consistently informed by neoclassical economics even following changes to the Washington Consensus (Ban, 2015; Park and Vetterlein, 2010b). While the IMF has always framed fossil fuel subsidies as well as other subsidies in terms of their negative fiscal consequences, the framing in terms of macroeconomic and especially environmental consequences increased in salience after 2008 because of the aforementioned entrepreneurship. The framing of subsidies as producing suboptimal societal outcomes has long been present within the IMF (see e.g. Gupta et al., 2000), but the focus on the macroeconomic costs of pollution (framing environmental degradation in terms of economic costs) only gained traction after 2008 (Arze del Granado and Gillingham, 2012; Clements et al., 2013; IMF, 2008a, 2008b). Hence, the entrepreneurs successfully defined 
fossil fuel subsidies in a way that resonated with the organisation's institutional worldview including the professional background of IMF officials, and leading to a very ideal-typical instance of economisation. This resonance is evident not just in the way in which the Fund has addressed fossil fuel subsidies, but also in how it has addressed climate change in general. Most notably, the 2019 report was part of a broader trend of IMF output addressing the economic aspects of climate change such as fiscal policies to meet the Paris Agreement (IMF, 2019c), the greening of the financial system (Carney, 2019; Grippa et al., 2019), using whales as carbon sinks (Chami et al., 2019) and a bilateral assessment of the climate policies of Belize and Grenada (IMF, 2019b, 2019d). Thus, the economisation of fossil fuel subsidies was part of a larger wave of economisation of climate related issues. While the economisation of fossil fuel subsidies was a frontrunner for the IMF's economisation of climate issues, arguably the more overarching economisation and inherent attention to climate issues was an environment conducive to continued attention to fossil fuel subsidies.

Other factors were less important. Relations with member states were not particularly important, as is evident in the IMF reports stating that virtually all countries have fossil fuel subsidies, conclusions that ran directly against the claims of influential member states such as the United Kingdom and Japan. The IMF's de facto call for carbon taxes also goes against the current policy situation in the majority of member states (including the most influential member state the United States), which have not adopted such taxes. These states broadly endorsed the IMF's 2019 efforts to address mitigation when they were presented as proposals to the Board (interview with senior IMF official, 19 May 2020). Institutional interaction was also limited, beyond the aforementioned group of Washington-based economists at inter alia the IMF and the World Bank, who discussed the notion of including environmental externalities in estimates of efficient fuel prices, and the use of OECD production subsidy data. The IMF was not one of the institutions requested by the G20 to provide reports fossil fuel subsidies in the way that it provided reports on climate finance (see Chapter 12). Although IMF officials have participated in various meetings of fossil fuel experts inter alia in the context of the G20, this interaction has had no significant influence on the decision to address fossil fuel subsidies and how it addressed them.

\subsection{Consequences}

\subsubsection{International Consequences}

The IMF's notion of including the non-pricing of externalities in the definition of fossil fuel subsidies constituted a radical break with previous definitions of fossil 
fuel subsidies, especially those by the IEA and the OECD. Yet, it has not led to similarly radical changes in the politics of fossil fuel subsidies at the international level. It did not have an incentive-based influence over other institutions, and although ideational and agenda-setting influences were present, they were also limited. Perhaps because of its radical break with more established definitions or because it ran against the preferences of most states, there were limits to the willingness to use the IMF's definition in other intergovernmental institutions. Regarding the G20, IMF officials have participated in the peer review of China, which also referred lengthily to the IMF's reports and their analysis of the nonpricing of the externalities from fossil fuels in China (G20, 2016a). Other peer reviews also brought up the issue of addressing externalities, inter alia through 'corrective taxation' (G20,2016b), but did not rely on an IMF analysis or the notion of 'getting prices right' to the same degree as the China peer review (G20, 2016a). Furthermore, the attention to addressing externalities has gradually declined since the US and China peer reviews in 2016. The 2017 peer reviews of Mexico and particularly Germany discussed non-pricing of (especially environmental) externalities as possibly constituting a fossil fuel subsidy and in the German review referring to IMF data, the 2019 reviews of Indonesia and Italy did not address the issue (G20, 2017b, 2017c, 2019b, 2019c). ${ }^{5}$

The differences between the peer reviews underscore that the influence of the IMF output was to a large degree contingent on IMF participation in the peer review (the China peer review) and has declined over time. None of the peer reviews included non-priced externalities in their definition of fossil fuel subsidies. Thus, there was some agenda-setting influence in terms of urging the G20 to address such non-pricing, cognitive influence in terms of providing new knowledge about such non-pricing in the countries reviewed and normative influence in terms of recommending addressing this non-pricing. Without the IMF reports, it is unlikely that the non-pricing would have been addressed to the same extent. Yet, crucially, the nonpricing of externalities was not defined by the G20 as a fossil fuel subsidy, and hence, it was not framed as an issue where the norm of fossil fuel subsidy reform would be salient.

Beyond the G20, the actors tasked with measuring progress towards Sustainable Development Goals (SDGs, led by the United Nations Environment Programme [UNEP] and the International Institute for Sustainable Development [IISD] with significant OECD involvement) discussed the IMF's definition at great length and compared it to the OECD and IEA definitions, but chose not to include the nonpricing of externalities in its definition, instead opting for an approach closer to the OECD's (see Chapter 6). IMF staff were not part of the development of the SDG 12.c

\footnotetext{
${ }^{5}$ The G20 did not publish any peer reviews in 2018 .
} 
indicator. The IMF's approach has proven more popular among environmental NGOs, a community not otherwise known for embracing the IMF. The Health and Environment Alliance (Nandi, 2017) and the Climate Action Network Europe (2017) are among the NGOs that have been inspired by the IMF's large estimates and the inclusion of non-priced externalities under the heading of subsidies, and used these cognitive ideas to promote climate policies.

\subsubsection{Domestic Consequences}

The IMF's output has had more pronounced consequences at the domestic level than at the international level. ${ }^{6}$ Particularly the Fund's programmes have had an important incentive-based impact on domestic fossil fuel subsidy reform in a range of countries, including Egypt, Sudan and Ukraine (IMF, 2015c; Michael, 2013; Sherry et al., 2014). The IMF made the provision of loans that the country was not able to obtain from other sources conditional upon far-reaching fiscal reform, including fossil fuel subsidy reform. Identifying ideational and agenda-setting consequences requires a more detailed look at individual countries, which is why the chapter turns to the five country cases.

In the case of the United States, the IMF estimated that fossil fuel subsidies in the United States totalled USD 649 billion in 2015, of which non-priced externalities constitute US 647 billion (Coady et al., 2019). The IMF had no incentive-based influence, as the United States has not been subject to a lending arrangement since 1965 and limited impact on the public and policymaking agendas. Regarding the public agenda (see Table 7.1), the IMF's 2015 and 2019 reports on the size of global

Table 7.1 Fossil fuel subsidies and the IMF in the US media: New York Times and Washington Post

\begin{tabular}{llllllllllllll}
\hline \hline & 2009 & 2010 & 2011 & 2012 & 2013 & 2014 & 2015 & 2016 & 2017 & 2018 & 2019 & Total \\
\hline $\begin{array}{l}\text { Articles referring to } \\
\quad\end{array}$ & $0)$ & 0 & 0 & 0 & 0 & 0 & 3 & 0 & 0 & 0 & 1 & 4 \\
$\begin{array}{l}\text { US fossil fuel } \\
\text { subsidy reform }\end{array}$ & & & & & & & & & & & & \\
$\quad \begin{array}{l}\text { and the IMF } \\
\text { All articles referring } \\
\text { to fossil fuel sub- }\end{array}$ & 6 & 20 & 22 & 9 & 8 & 16 & 0 & 0 & 1 & 15 & $\mathbf{1 0 0}$ \\
sidy reform \\
(international and \\
domestic)
\end{tabular}

${ }^{6}$ This section expands on and updates Skovgaard (2018). 
fossil fuel subsidies were referenced a few times in newspaper articles that also explicitly linked them to US subsidies, but without initiating a major policy debate (Mooney, 2015; Schwartz, 2015). The IMFs reports on fossil fuel subsidies and the notion of non-priced externalities as a subsidy did not have a significant influence on the policy agenda at the national level, where carbon pricing has been very controversial since 2009, when the Waxman-Markey proposal for a US emissions trading system floundered in the Senate. Thus, there have not been any attempts (IMF-inspired or otherwise) to link fossil fuel subsidy reform and carbon pricing at the federal level in the United States ${ }^{7}$, although there have been separate attempts to introduce both carbon pricing and fossil fuel subsidy reform at the federal level. As mentioned in Chapter 5, the debate over fossil fuel subsidy reform in the United States has been framed in domestic terms.

In terms of ideational consequences, Treasury officials interacted with the IMF officials who drafted the IMF definition on fossil fuel subsidies, something which developed the cognitive understanding of the issue in both organisations (interview with senior IMF economist, 24 April 2014). Yet this collaboration did not induce the Treasury to adopt a price-gap approach including environmental externalities in the way the IMF's definition of fossil fuel subsidies does (Clements et al., 2013). Perhaps the most important ideational influence of the IMF was its participation in the G20 peer review of the United States (see Section 5.3.2). In this case, the IMF managed to ensure that the non-pricing of externalities was included on the agenda in the context of the United States, but without any longer-term changes to the policy agenda or to policy itself.

Regarding the United Kingdom, the IMF estimated British fossil fuel subsidies at GBP 28 billion, which virtually only consisted of non-priced externalities (Coady et al., 2019). Incentive-based influences were absent since the last lending arrangement ended in 1979. Agenda-setting and ideational influences were relevant, especially in the context of the inquiry of the House of Commons Environmental Audit Committee into British fossil fuel subsidies (see also Chapter 5). The Committee referred to the IMF's 2013 report and the notion of defining nonpriced externalities as a subsidy, but in the end opted for excluding such externalities in the definition they used (House of Commons Environmental Audit Committee, 2013). The IMF's 2013, 2015 and 2019 reports were also picked up by British media (see Table 7.2), which highlighted its high estimates of global and (in 2013 and 2015) British fossil fuel subsidies (Carrington, 2015b; Watkins, 2013). The contradiction between the promises to fight climate change made in 2015 in the run-up to twenty-first Conference of the Parties to the United Nations Framework

7 Studying the relationship between these two concepts at the state level, where carbon pricing has been discussed and adopted in a number of states, is beyond the scope of this book. 
Table 7.2 Fossil fuel subsidies and the IMF in the UK media: The Guardian and The Independent

\begin{tabular}{|c|c|c|c|c|c|c|c|c|c|c|c|c|}
\hline & 2009 & 2010 & 2011 & 2012 & 2013 & 2014 & 2015 & 2016 & 2017 & 2018 & 2019 & Total \\
\hline $\begin{array}{l}\text { Articles referring to } \\
\text { UK fossil fuel } \\
\text { subsidy reform } \\
\text { and the IMF }\end{array}$ & 0 & 0 & 0 & 0 & 2 & 1 & 5 & 0 & 0 & 0 & 1 & 9 \\
\hline $\begin{array}{l}\text { All articles referring } \\
\text { to fossil fuel sub- } \\
\text { sidy reform } \\
\text { (international and } \\
\text { domestic) }\end{array}$ & 0 & 0 & 8 & 11 & 10 & 9 & 27 & 11 & 18 & 16 & 46 & 156 \\
\hline
\end{tabular}

Convention on Climate Change (COP21) in Paris and the persistence of British subsidies were highlighted in particular (Carrington, 2015b).

In terms of cognitive influences, the UK Treasury was responsible for both the UK government's definition of fossil fuel subsidies and for the IMF, and hence Treasury officials interacted regularly with IMF officials. This interaction increased awareness of the issue but did not amount to fundamental ideational influences on the Treasury officials. This was mainly because even before the IMF became closely involved in fossil fuel subsidies, the Treasury perceived fossil fuel subsidies in terms similar to that of the IMF's overarching view, namely as undesirable first because of their macroeconomic effects and secondly on the grounds of the environmental effects (interview with UK Treasury official, 24 November 2014; for an example of how the Treasury perceived fossil fuel subsidies through an environmental economics perspective, see Stern, 2006). Yet, the Treasury did not concur with the Fund that non-priced externalities constitute fossil fuel subsidies.

Concerning India, the consequences of IMF output have been more limited. The IMF estimated that Indian fossil fuel subsidies amounted to USD 209 billion in 2015, of which non-taxed externalities constituted more than USD 200 billion (Coady et al., 2019). India's last lending arrangement with the Fund (the largest ever) ended in 1993, ruling out incentive-based influences. The influence on the public agenda is also non-existent: only one article in the two leading Indian dailies referred to the IMF output, and this was only a reference to an analysis by an NGO made using the IMF's fossil fuel subsidy data (see Table 7.3).

India's successful fossil fuel subsidy reform has been driven by fiscal and macroeconomic concerns: there are cheaper ways of alleviating poverty, and fossil fuel subsidies are detrimental to the public budget and the balance of trade (see also Chapter 5). Two contextual factors made the reform possible: low oil prices and the 
Table 7.3 Fossil fuel subsidies and the IMF in the Indian media: The Hindu and Times of India

\begin{tabular}{|c|c|c|c|c|c|c|c|c|c|c|c|c|}
\hline & 2009 & 2010 & 2011 & 2012 & 2013 & 2014 & 2015 & 2016 & 2017 & 2018 & 2019 & Total \\
\hline $\begin{array}{l}\text { Articles referring to } \\
\text { Indian fossil fuel } \\
\text { subsidy reform } \\
\text { and the IMF }\end{array}$ & 0 & 0 & 0 & 0 & 0 & 0 & 0 & 0 & 1 & 0 & 0 & 1 \\
\hline $\begin{array}{l}\text { All articles referring } \\
\text { to fossil fuel sub- } \\
\text { sidy reform } \\
\text { (international and } \\
\text { domestic) }\end{array}$ & 0 & 1 & 10 & 35 & 37 & 19 & 17 & 4 & 7 & 4 & 4 & 138 \\
\hline
\end{tabular}

liberalisation of the Indian economy ongoing since the early 1990s. Low oil prices created the scope in which to liberalise fuel prices without attracting public protests. Although the liberalisation of the Indian economy is arguably the result of ideational influences promoting the belief in free-market economic governance (Mukherji, 2013), more specific ideational influences concerning fossil fuel subsidies have not been significant. Rather they have been limited by scepticism of the framing of fossil fuel subsidies as an environmental issue, since the Indian government frames them as an economic and fiscal issue (Dasgupta, 2013). The scepticism reflects the historically predominant (yet increasingly challenged) view within the Indian elite that climate change is the responsibility of developed countries and that developing countries should not commit to climate change actions (Sengupta, 2019; Thaker and Leiserowitz, 2014).

Indonesia constitutes a different case as regards IMF influence. The IMF estimated Indonesian fossil fuel subsidies at USD 97 billion in 2015, of which nontaxed externalities constituted USD 86 billion (Coady et al., 2019). Incentive-based effects were important in 2002 (and thus before the period in question here), when the IMF programme following the 1997-8 Asian financial crisis led to increases in fixed fuel prices (Government of Indonesia, 2002). After this programme ended in 2003, the absence of direct leverage meant that the IMF played the part of a trusted policy advisor rather than an active stakeholder (former senior IMF official, interview, 14 December 2016). However, the drivers of more recent Indonesian fossil fuel subsidy reforms are primarily domestic (interviews with officials from the Indonesian Ministry of Finance and Bappenas, 14 September 2016 and 20 December 2016). The Indonesian Ministry of Finance has been an important driver of such reforms (and interacted closely with the World Bank) because of 
Table 7.4 Fossil fuel subsidies and the IMF in the Indonesian media: Kompass and Tempo

\begin{tabular}{llllllllllllll}
\hline \hline & 2009 & 2010 & 2011 & 2012 & 2013 & 2014 & 2015 & 2016 & 2017 & 2018 & 2019 & Total \\
\hline $\begin{array}{l}\text { Articles referring to } \\
\text { Indonesian fossil }\end{array}$ & 0 & 0 & 0 & 4 & 2 & 0 & 0 & 0 & 0 & 2 & 0 & $\mathbf{8}$ \\
fuel subsidy \\
reform and \\
the IMF
\end{tabular}

concerns about their impact on the budget (interview with senior Indonesian Ministry of Finance official, 26 February 2016).

The IMF's knowledge output in the shape of reports has also to some degree been picked up by the Indonesian media (see Table 7.4), including IMF data on the magnitude of Indonesian non-priced externalities and suggestions for how to reform fossil fuel subsidies (Nasution, 2013). Furthermore, the IMF has been cognitively influential in providing analyses of Indonesian fossil fuel subsidies in collaboration with the World Bank. The IMF collaborated with the World Bank, following a standard division of labour in which the IMF focused more on the monetary exchange rate and broad fiscal setting, while the World Bank focused on sectoral and microeconomic issues (former senior IMF official, interview, 14 December 2016).

Finally, in the case of Denmark, according to the IMF, fossil fuel subsidies in Denmark amount to USD 6.3 billion, only consisting of non-taxed externalities (Coady et al., 2019). Denmark has never been subject to an IMF programme, and incentive-based influences did not play a role. As regards influences on the public agenda, only one newspaper article has referred to the IMF's estimates (see Table 7.5). Yet, concerning the policymaking agenda and cognitive influences, green politicians have referred to the IMF's estimate that Danish fossil fuel subsidies amount to USD 1,000 per capita and forced the government to admit to having fossil fuel production subsidies (Danish Ministry of Climate Change, 2015; Poll, 2016). Various Danish governments have consistently argued that the high levels of the Danish carbon tax means that it does not make sense to speak about Danish consumption subsidies, thus disputing the IMF's definition. When there were discussions within the Danish government of a self-review of Danish fossil fuel subsidies (see also Chapter 6), the OECD definition was preferred to the IMF one, which was considered - by the Danish government as well as by several other 
Table 7.5 Fossil fuel subsidies and the IMF in the Danish media: Politiken and Jyllands-Posten

\begin{tabular}{|c|c|c|c|c|c|c|c|c|c|c|c|c|}
\hline & 2009 & 2010 & 2011 & 2012 & 2013 & 2014 & 2015 & 2016 & 2017 & 2018 & 2019 & Total \\
\hline $\begin{array}{l}\text { Articles referring to } \\
\text { Danish fossil fuel } \\
\text { subsidy reform } \\
\text { and the IMF }\end{array}$ & 0 & 0 & 0 & 0 & 0 & 0 & 0 & 1 & 0 & 0 & 0 & 1 \\
\hline $\begin{array}{l}\text { All articles referring } \\
\text { to fossil fuel sub- } \\
\text { sidy reform } \\
\text { (international and } \\
\text { domestic) }\end{array}$ & 0 & 0 & 3 & 3 & 5 & 8 & 9 & 1 & 10 & 4 & 13 & 56 \\
\hline
\end{tabular}

countries - too far-reaching (interview with former Danish senior civil servant, 5 May 2020).

\subsection{Summary}

As regards fossil fuel subsidies, the IMF turned out in many ways to be the unexpected environmentalist. The Fund's output can be divided into two strands. First, the IMF has for decades induced countries to reform their fossil fuel subsidies through the conditionalities of its programmes, but until recently without treating fossil fuel subsidies differently than any other subsidy. Second, since 2008, the IMF has defined the non-pricing of externalities including climate change as constituting a subsidy. This definition constitutes a game changer in IMF policy on the subject, which was driven by policy entrepreneurs among the IMF officials and was shaped by the economic worldview of the IMF in the context of the IMF bureaucracy's autonomy from its member states. The IMF's output has had some ideational impact on the international level, where other institutions such as the G20 took the IMF's definition of fossil fuel subsidies into account but ended up relying on other definitions. The output has had more important consequences for the domestic level. The first strand had decisive incentive-based consequences for countries such as Indonesia under IMF lending arrangements, which required them to reform their fossil fuel subsidies. The IMF's extensive definition of fossil fuel subsidies, according to which practically all countries in the world subsidise fossil fuels, also had an impact. It was utilised by actors who wanted fossil fuel subsidy reform in countries such as Denmark and the United Kingdom. 